Corresponding Author: Petrus Belarminus; email: petrusmr71@gmail.com

Published: 7 February 2022

Publishing services provided by Knowledge E

(c) Petrus Belarminus and Grasiana Florida Boa. This article is distributed under the terms of the Creative Commons

Attribution License, which permits unrestricted use and redistribution provided that the original author and source are credited.

Selection and Peer-review under the responsibility of the IVCN Conference Committee.

\section{Factors Affecting the Occurrence of Coronary Heart Disease in the General Hospital of Waikabubak, Indonesia}

\section{Petrus Belarminus* and Grasiana Florida Boa}

Department of Nursing, Poltekkes Waikabubak, Kupang, Indonesia

\section{ORCID}

Petrus Belarminus: https://orcid.org/0000-0001-5243-137X

Abstract. Coronary heart disease (CHD) causes many deaths. It is a disease of the heart that occurs due to decreased blood supply to the heart muscle. Risk factors that can trigger CHD can be grouped into two categories, namely those that cannot be modified and those that can. The risk factors that cannot be modified include heredity, age and gender, while the modifiable risk factors include smoking, hypertension, increased serum cholesterol levels, obesity and diabetes. Basic Health Research data show that in 2018, $1.5 \%$ or 15 out of 1000 Indonesians suffered from CHD. The aim of this study was to investigate the factors that influence the incidence of CHD at the RSUD Waikabubak. This was a quantitative analytical survey which used a cross-sectional approach. According to the results, $\mathrm{CHD}$ was significantly associated with gender (OR $=3.5, p=0.011)$, smoking ( $O R=3.9, p=0.006)$ and hypertension $(O R=4.8, p=0.001)$. Of the factors studied, hypertension had the strongest influence on the incidence of CHD.

Keywords: coronary heart disease, the factors that influence

\section{Introduction}

$\mathrm{CHD}$ is a cardiovascular disease that causes many deaths. The term coronary heart disease is a disease of the heart that occurs due to decreased blood supply to the heart muscle, resulting in sudden death, heart rhythm disturbances or heart failure.

WHO data in 2015 showed that more than 17 million people in the world died from heart and blood vessel disease. About $30 \%$ of all deaths in the world, mostly or around 8.7 million, are caused by coronary heart disease. More than $75 \%$ of deaths from heart and blood vessel disease occur in developing countries [1].

The public service communication bureau of the Indonesian Ministry of Health, in a release published November 10, 2018, said that in Indonesia the results of the 2018 Basic Health Research showed that $1.5 \%$ or 15 out of 1000 Indonesians suffer from coronary heart disease [2]. In addition, the 2018 Riskesdas data shows that the prevalence of heart disease based on doctor's diagnosis in Indonesia is $1.5 \%$ with the highest prevalence rating, one of which is DKI Jakarta at $1.9 \%$. 
factors that can trigger CHD can be grouped into two categories, namely risk factors that cannot be modified and those that can be modified. The risk factors that cannot be modified include heredity, age, and gender. While the risk factors that cannot be modified include smoking, hypertension, increased serum cholesterol levels, obesity, and diabetes [3].

The results of a preliminary study conducted in December 2019 regarding coronary heart disease at the RSUD Waikabubak, it was reported that the last 3 years the percentage of CHD cases had increased compared to other disease cases. In 2016 it was 19.7\%, in 2017 it was $20.6 \%$ and in 2018 it was 20.8\% [4]. Therefore, the authors are interested in conducting research with the title of factors that influence the incidence of coronary heart disease at the RSUD Waikabubak.

\section{Methods}

\subsection{Design}

This research is analytical research with a cross sectional approach which aims to obtain information about the factors that influence the incidence of coronary heart disease at the RSUD Waikabubak.

\subsection{Sample}

The sample in this study were patients at the RSUD Waikabubak who were experiencing coronary heart disease in 2019 . The number of samples using the Slovin formula was obtained by 85 samples.

\subsection{Procedure}

The sample in this study were patients at the RSUD Waikabubak who were experiencing coronary heart disease in 2019. The sampling technique used was systematic random sampling of multiples of 7 starting from number 7 until the sample needs were met. 
TABLE 1: Distribution of Coronary Heart Disease Frequency at RSUD Waikabubak.

Coronary Heart Disease
UAP
IMA
Total

\begin{tabular}{|l|l|}
\hline$F$ & $\%$ \\
\hline 42 & 49,4 \\
\hline 43 & 50,6 \\
\hline 85 & 100.0 \\
\hline
\end{tabular}

TABLE 2: Gender Frequency Distribution at RSUD Waikabubak.

Gender
Male
Female
Total

\begin{tabular}{l|l}
\hline$F$ & $\%$ \\
\hline 48 & 56,5 \\
\hline 37 & 43,5 \\
\hline 85 & 100.0 \\
\hline
\end{tabular}

\subsection{Data Collection}

The variables taken in this study are the independent variables, namely gender, smoking, hypertension, and obesity. The data used in this study is secondary data, namely data obtained from medical records.

\subsection{Data Analysis}

The data were analyzed by SPSS/WIN version 23. Descriptive statistics were used to explain the demographic information of the respondents, as well as other research variables. chi-square test was used to find the relationship between variables. The $p$ value $<.05$ was considered significant.

\section{Results}

Based on the results of research at the RSUD Waikabubak, the frequency distribution of several variables can be shown, among others, based on:

\section{Discussion}

TABLE 3: Frequency Distribution at RSUD Waikabubak.

Smoke
Yes
No
Total

\begin{tabular}{|l|l|}
\hline$F$ & $\%$ \\
\hline 49 & 57,6 \\
\hline 36 & 42,4 \\
85 & 100.0 \\
\hline
\end{tabular}


TABLE 4: Distribution of Hypertension Frequency in RSUD Waikabubak.

\begin{tabular}{l|l|l} 
Hypertension & F & $\%$ \\
\hline Yes & 47 & 96.8 \\
\hline No & 38 & 3.2 \\
\hline Total & 85 & 100.0
\end{tabular}

TABLE 5: Distribution of Obesity Frequency in RSUD Waikabubak.

\begin{tabular}{l|l|l} 
Obesity & F & $\%$ \\
\hline Yes & 45 & 52,9 \\
No & 40 & 47,1 \\
\hline Total & 85 & 100.0
\end{tabular}

\subsection{Relationship between Sex and Coronary Heart Disease at RSUD Waikabubak}

Based on the results of the analysis, it can be seen that the results of the bivariate test between gender and coronary heart disease were found to be 48 men, $62.5 \%$ of whom suffered from UAP CHD. while women from 37 respondents, $67.6 \%$ of them suffer from CHD IMA. From the results of the bivariate analysis, the $p$ value $=0.011(<0.050)$, thus it can be said that there is a significant relationship (significant) between gender and patients with coronary heart disease at the RSUD Waikabubak. Odd Ratio (OR) is obtained = $3.5(1.4-8.5)$ with a lower limit of 1.4 and an upper limit of 8.6 , which means that men have a $3.5 \mathrm{X}$ chance of $\mathrm{CHD}$ compared to women.

The results of this study are in accordance with the theory where gender is the difference between women and men biologically since a person is born. In the United States, CHD symptoms are found in 1 in 5 men and 1 in 17 women, this means that men have a risk of CHD 2-3 times greater than women. In some women using contraceptives (estrogen) and during pregnancy will increase cholesterol levels. In large pregnant women, cholesterol levels will return to normal 20 weeks after giving birth [5].

Estrogens can increase the mechanism of $\mathrm{CHD}$, including: increased total serum cholesterol, increased LDL, increased serum triglycerides, glucose intolerance (DM), thrombocytosis tendency, increased BP and coronary artery smooth muscle tone. The mortality rate at young ages is higher in men than in women, but after menopause, there is almost no difference in mortality between men and women [6-8].

Diana Zahrawardani [9] Research Results, In 2013 the results of the analysis of 128 research samples, the majority were male, as many as $68.80 \%$. Observational study at Framingham in terms of gender, most CHD occurs in men (60\%) compared to women 
(40\%). Coronary heart disease is the cause of $40 \%$ of male deaths at the age of $55-65$ years.

In contrast to Donald Nababan's [10] research at RSU Dr. Pirngadi Medan, out of 70 people there were $67.1 \%$ women and $32.9 \%$ men, where there were more women than men. 8.9. Statistical test results obtained $p$ value $=0.293(p>0.05)$ meaning that there is no significant relationship between gender and the incidence of $\mathrm{CHD}$ in Dr Kariadi Hospital Semarang. However, the results of research by [11], which states that there is a relationship between gender and the incidence of $\mathrm{CHD}(p=0.008)$. This may happen because around 50 years and over, women and men have the same level of risk and in this study the majority of patients were $\mathbf{4 5}$ years old. Medically it can also attack anyone, both men and women [11,12].

Women who use contraception (estrogens) and postmenopausal women have a higher risk of developing CHD. Therefore, according to researchers, women should be more careful because they are more at risk of $\mathrm{CHD}$ than men.

\subsection{Relationship with Coronary Heart Disease at RSUD Waikabubak, 2019}

Based on the results of the analysis, it can be seen that the results of the bivariate test between smoking and coronary heart disease were obtained from 49 respondents who smoked, $63.3 \%$ of whom suffered from UAP CHD, and from 36 respondents, $69.4 \%$ suffered from AMI. CHD. From the results of the bivariate analysis, it was found that $p$ value $=0.006(<0.050)$, so it can be said that there is a significant (significant) relationship between smoking and coronary heart disease patients at the RSUD Waikabubak for the 2019 period. Odd Ratio (OR) obtained = $3.9(1.6-9.8)$ with a lower limit of 1.6 and an upper limit of 9.8 which means that smokers have a $3.9 \mathrm{X}$ chance of $\mathrm{CHD}$ compared to non-smokers.

The results of this study are in accordance with the theory where smoking is an activity of smoking or cigarettes produced. Cigarettes are processed tobacco products in packaging including cigars or other forms produced from the plants nicotiona tabacum, nicotiona rustica, and other types containing nicotine and tar with or without additives [13].

There are various types of smokers which are measured by various things, one of which is measured by the intensity of smoking. Smoking intensity is the frequency of smoking activities that are always carried out by individuals such as lighting, lighting 
and feeling it. The intensity of smoking for one day is divided into two types, namely light smokers ( 5 cigarettes per day) and heavy smokers ( 5 cigarettes per day).

According to [9], smoking is a major risk factor for heart disease, including heart attack and stroke, and also has a strong relationship with the occurrence of CHD so that quitting smoking will reduce the risk of heart attack. Inhaling as soon as possible will increase the level of $\mathrm{CO}$ in hemoglobin so that less oxygen is supplied to the heart, working harder to produce the same amount of energy. The content of nicotinic acid in tobacco triggers the release of catecholamines which can cause narrowing of the arteries, so that blood flow and tissue oxygenation are disrupted. SSH can also increase platelet adhesion, which can promote thrombus formation.

The results of research conducted by Ros Enda at RSUD Dr. Moewardi Surakarta in 2017 showed a significant influence between smoking habits and the incidence of CHD ( $p=0.140$ ). and $O R=4,500$ which means that smoking is a risk factor that affects the incidence of CHD. In addition, the results of research conducted by [14] were conducted in hospitals. Kariadi Semarang that smoking has a 2.4 greater risk of suffering from myocardial infarction.

Chemical substances contained in cigarettes are very dangerous for the body, especially for the health of smokers themselves, including one of them is the cause of cardiovascular disease so that according to researchers it is hoped that men and women do not smoke to avoid coronary heart disease.

\subsection{Relationship between Hypertension and Coronary Heart Dis- ease at the RSUD Waikabubak in, 2019}

The results of the analysis can be seen the results of the bivariate test between hypertension and coronary heart disease, obtained from 47 respondents who had hypertension, $66 \%$ of them suffered from UAP CHD and 38 respondents who did not hypertension, $71.1 \%$ of them suffered from AMI CHD. From the results of the bivariate analysis, the $p$ value $=0.001(<0.050)$, thus it can be said that there is a significant relationship between hypertension and patients with coronary heart disease at the RSUD Waikabubak for the 2019 period. Odd Ratio (OR) is obtained $=4.8=5(1.9-11.9)$ with a lower limit of 1.9 and an upper limit of 11.9, meaning that hypertension has a $5 \mathrm{X}$ chance of CHD compared to those without hypertension.

The results are in accordance with the theory that hypertension in general can be defined as a systolic pressure of $140 \mathrm{mmHg}$ and a diastolic pressure of $90 \mathrm{mmHg}$. According to $\mathrm{WHO}$, the normal limit for blood pressure is $120-140 \mathrm{mmHg}$ systolic 
pressure and $80-90 \mathrm{mmHg}$ diastolic pressure. Hypertension in a person when the diastolic pressure is $90 \mathrm{mmHg}$ and the systolic pressure is $140 \mathrm{mmHg}$. Hypertension is a risk factor that plays an important role in coronary heart disease and the process of arteriosclerosis will be experienced by about $30 \%$ of hypertensive patients.

Hypertension is also known as an observable risk factor for CHD. Hypertension is a factor that plays a role in causing myocardial infarction, stroke, heart failure, kidney failure and retinopathy. Hypertension can increase the resistance to pumping blood from the left ventricle and cause dilatation of the heart. Atherosclerosis process that continues with age continues to occur, the supply of oxygen to the myocardium will decrease, while its need increases due to ventricular hypertrophy and an increase in the workload of the heart which can eventually lead to angina or myocardial infarction [15].

The results of this study are in accordance with the results of research conducted by Lily Marleni on Risk Factors for Coronary Heart Disease at RSI SITI Khadijah Palembang in 2017, proving that there is a significant relationship between hypertension and coronary heart disease $(p$-value $=0.012$ ). Hypertension in a person when diastolic pressure is $90 \mathrm{mmHg}$ and systolic pressure is $140 \mathrm{mmHg}$, therefore, according to researchers, we should regularly check blood pressure and maintain a diet so that blood pressure is controlled, so as to avoid Coronary Disease.

\subsection{The Relationship between Obesity and Coronary Heart Dis- ease at the RSUD Waikabubak}

Based on the results of the analysis of table 5.9 above, it can be seen that the results of the bivariate test between hypertension and coronary heart disease were obtained from 45 respondents who were obese, $64.4 \%$ of whom suffered from UAP CHD and 40 respondents who were not obese, $67.5 \%$ of whom suffered from AMI CHD. From the results of the bivariate analysis, the $p$ value $=0.006(<0.050)$, thus it can be said that there is a significant relationship between obesity and patients with coronary heart disease at the RSUD Waikabubak for the period 2019. Odd Ratio (OR) is obtained $=3$ ,8 (1.5 - 9.3) with a lower limit of 1.5 and an upper limit of 9.3 , which means that obesity has a $3.8 \times$ chance of CHD compared to those who are not obese.

The results of this study are in accordance with the theory which according to WHO (1998) obesity is a state of excessive accumulation of body fat. In other words, obesity can be interpreted as a disorder or disease characterized by excessive accumulation of body fat. 
Overweight or overweight is a condition where a person's weight exceeds the normal weight. Obesity is a state of excess triacyl glycerol in fat tissue due to excess energy intake compared to its use. Obesity is also associated with diseases that can reduce the quality of life. Obesity occurs if over a period of time more calories enter through food than are used to support the body's energy needs.

The Global Burden of Metabolic Risk Factors for Chronic Diseases Collaboration which combines 97 cohort studies with research locations spread throughout the world, also proves that obesity has a significant relationship to coronary heart disease between obesity and coronary heart disease. This study resulted in a pooled RR of 1.69 (95\% Cl1.58-1.81).

The existence of significant results between obesity and coronary heart disease is because obesity can increase blood pressure, triglyceride levels, cholesterol, glucose resistance, and blood clots. Increased blood pressure makes blood vessels susceptible to thickening and narrowing. This if it occurs in the coronary arteries will cause coronary heart disease. Likewise, if there is an increase in triglyceride and cholesterol levels, this will trigger the appearance of plaque thrombosis in the blood vessels. It can also cause coronary heart disease.

Obesity in adults is determined by body mass index (BMI) or Body Mass Index (BMI). $\mathrm{BMl}$ is an anthropometric measurement to assess whether the body components are in accordance with normal or ideal standards. It is obtained by dividing body weight (KG) by the square of height.

\section{Funding}

We Declare no funding for this study.

\section{Conflict of Interest}

We declare no conflict of interest.

\section{References}

[1] Apris A, Muh. Serum uric acid levels with the severity of stenosis in coronary heart disease. Ponorogo: Uwais Inspirasi Indonesia; 2019.

[2] Brown CT. Pathophysiology: Clinical concepts of disease processes. 6th ed. Price SA, Wilson LM, editors. Jakarta: EGC; 2015. 
[3] Hastuti P. Obesity genetics. Yogyakarta: Gajah Mada University Press; 2017.

[4] Karikaturijo. Coronary heart disease. Jakarta: Universitas Pembangunan Nasional; 2014.

[5] Black JM, Hawks JH. Medical surgical nursing: Clinical management for expected outcomes. 8th ed. Jakarta: Elsevier; 2014.

[6] Omega DR. Statistics for health, wahana resolusi. Yogyakarta: 2017.

[7] Sandra T, et al. Healthy living without cigarette smoke. Kemenkes Rl; 2017.

[8] Sitorus R. Disease symptoms and prevention. Bandung: Yrama Widya; 2014.

[9] Zahrawardani D. Analysis of risk factors for coronary heart disease at Dr Kariadi Hospital, Semarang. 2013.

[10] Nababan, D. Hubungan Faktor Risiko dan Karakteristik Penderita dengan Kejadian Penyakit Jantung Koroner di RSU Dr. Pirngadi Medan Tahun 2008. 2008. Medan. Universitas Sumatera Utara.

[11] Sudaryo T, et al. Diet and obesity. Yogyakarta: Gajah Mada University Press; 2014.

[12] Amrock SM, Weitzman. Adolescent perception of light and intermittent smoking in the United States. Pediatrics. 2015.

[13] Ramadhan A. Coronary heart disease doesn't have to end in death. Kompas; 2016 Dec 18 [cited 2020 Dec 30]. Available from: https://amp.kompas.com/lifestyle/read/ 2016/10/18/170000223/penyakit.jantung.koroner.tak.harus.berujung.kematian

[14] Iskandar. Risk factors for coronary heart disease in Meuraxa General Hospital patients, Banda Aceh. 2013.

[15] Kemenkes RI. World heart day 2019: Healthy heart, excellent HR. Kemkes.go. Available from: http://www.p2ptm.kemkes.go.id/kegiatan-p2ptm/pusat-/hari-jantungsedunia-hjs-tahun-2019-jantung-sehat-sdmunggul/P2PTM 